\title{
CONTEMPORARY POLITICAL, LEGAL AND ECONOMIC ASPECTS OF AVIATION SAFETY
}

\author{
Dr. Grzegorz Zajac \\ Old Polish University in Kielce, Deputy Director of Institute of Safety and Health Protection \\ DOI: 10.46609/IJSSER.2020.v05i09.001 URL: https://doi.org/10.46609/IJSSER.2020.v05i09.001
}

\begin{abstract}
Safety is one of the major challenges of contemporary aviation. Because of the nature of civil aviation, it should be considered in terms of international cooperation. The basic issue in the functioning of the aviation industry is ensuring safety for all users and entities concerned. Firstly, it is the state's obligation that entities operating on the aviation market meet relevant international, regional or national standards. Secondly, passengers themselves want to use the most secure forms of transport. Finally, it is in the interest of the air carrier or airport to provide and offer services that are secure, which affects their economic condition. The better economic condition of an aviation industry, the better for the national and global economy. This institutional approach to the role of State safety allows us to emphasize, that it is not only the air carrier or airport that is responsible for air safety of its passengers, but above all the State through its bodies.

State policy must guarantee every user of the airspace and all entities related to the aviation industry that every effort will be made to ensure that from the legal point of view all standards of the provision of air services are safe. The State shall create and implement special rules and mechanisms to be applied by aviation entities in order to control and monitor the fulfillment of safety rules. Economic aspects of aviation safety are essential in the functioning of air operations and aviation business. The more safe the aviation is, the better macroeconomic results. Meeting the highest safety standards in aviation business is the core issue of each State and each international and regional organization.
\end{abstract}

Keywords: aviation safety, civil aviation, airport safety and security, passengers' safety

\section{Introduction}

The basic issue in the functioning of the aviation industry is to ensure the safety of all users concerned. What some might say that profitability of a company is a determinant of its existence. This is true, but whether it is an airport or an air carrier that does not meet the minimum safety 


\section{International Journal of Social Science and Economic Research}

ISSN: $2455-8834$

Volume:05, Issue:09 "September 2020"

requirements, then without a proper approach to the safety of air transport, such an entity will not stay on the very demanding and standardized air market.

The question is: why this is a demanding market? Every user wants to have the best conditions in terms of quality, organization and scope of the offer. At the same time, security issues are the basic, because failure to fulfill these requirements directly affects the quality of services, organization of the system and availability of the offer. Aviation authorities on behalf of the state will not allow them to be operational, unless they meet the relevant formal political safety requirements. It can happen, especially in less democratic countries, or in those where aviation regulations and standards are not so strictly observed. Nevertheless, social awareness increases in these places about the economic and social consequences of the negative image of the airport or air carrier for the whole country. Firstly, it is the state's obligation that entities acting on the aviation market meet relevant international, regional or national standards, and secondly, passengers themselves want to use the most secure forms of transport. Finally, it is in the interest of the air carrier or airport to provide and offer services that are secure. This rule affects their economic condition.

The next question we need to answer is: why the market is standardized? There are international regulations as well as standards and recommendations that must be respected in terms of safety. Not all of them are of a legal and binding nature, there are many recommendations which, due to the nature of the means of transport, should be considered taking into account their own interest and the interest of those to whom the service is addressed. International regulations form the basis for the functioning of all civil aviation. This particular document is the Convention on International Civil Aviation (Chicago Convention) of December 7, 1944 ${ }^{\mathrm{i}}$. In addition to this, there are legally binding annexes to this Convention setting out standards and recommended practices for the Member States. They are adopted by the Council of the International Civil Aviation Organization (ICAO), pursuant to Article 37 of the Convention. There are also regional, more detailed and sometimes more restrictive solutions regarding air transport safety in Europe, which are adopted under the auspices of the European Union (EU) or the Agency of the European Union for Aviation Safety (EASA). Other regions of the world are doing a bit worse with regional harmonization of regulations, which does not necessarily mean that safety standards must deviate from European ones. On the contrary, there are international regulations in each country, non-compliance with which is a violation of the international commitments of the States and involves the threat of imposing political or legal sanctions.

The performance of air operations by carriers is based on a number of requirements that the air carrier must meet. Airports must also meet certain international standards to be able to service both air carriers and passengers. The most important thing in the operation of each entity are the safety and security regulations. This issue is considered in the contemporary world in the context 
of such areas, i.e. ground handling safety, passenger service and check-in safety, aircraft takeoff and landing safety, air navigation safety, technical and operational safety of aircraft, etc.

Safety is one of the major challenges of contemporary aviation. In the international security dimension, because this is the core nature of civil aviation, they should be considered in terms of international cooperation, joint resolution of common problems and the ability to build universal

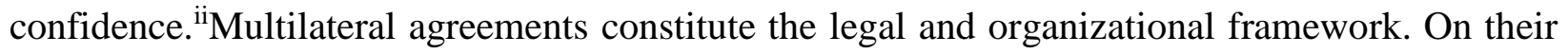
basis, the harmonization of regulations and practical activities of air transport entities, including countries is being carried out. Bilateral agreements, on the other hand, specify the provisions contained in the multilateral agreements and specify the air communication between the two parties. Bilateral agreements also include appropriate safety clauses so that countries in light of an aviation accident or a terrorist act targeting aviation know how to behave and it is easier for them to take immediate and appropriate action.

\section{International safetystandards}

The Chicago Convention is the foundation in the field of international safety standards, which was adopted by states so that international civil aviation may be developed in a safe and orderly manner and that international air transport services may be established on the basis of equality of opportunity and operated soundly and economically, and also taking into account that the future development of international civil aviation can greatly help to create and preserve friendship and understanding among the nations and peoples of the world, yet its abuse can become a threat to the general security. There must be one basic aviation safety order for all operating entities to be able to carry out their activities safely. The Chicago order is based on the provisions of the convention and annexes and documents regulating various aspects of aviation safety. There is currently no legal international definition of aviation safety. States see this category as a certain

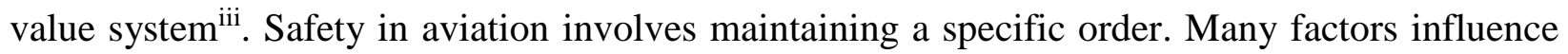
aviation safety, because it is a comprehensive issue covering a number of elements not directly related to it. It can be defined as a set of legal provisions regarding the production and maintenance of aircraft and the functioning of service providers and beneficiaries in the aviation environment, while aviation security covers the general organizational and legal framework as well as operational and technical prevention of illegal acts aimed at civil aviation (Zajac, 2016) ( $^{i v}$

These two definitions are mutually complementary, as ensuring an adequate level of aviation safety cannot take place without the adoption of appropriate measures and procedures to prevent acts of terrorism aimed at the aviation sector. In a broader sense, economic factors also influence safety (e.g. issue of sky defragmentation, air traffic management $-A T M$ ), or technical and 


\section{International Journal of Social Science and Economic Research}

ISSN: $2455-8834$

Volume:05, Issue:09 "September 2020"

operational factors (e.g. unification of technical standards, proper selection of slots (allowance to start and take-off from the airport).

The issue of civil aviation safety is found in many international documents, multilateral and bilateral agreements, in particular the basic provisions are contained in the Chicago Convention and its two annexes: Annex No 17 (,Aviation security”) as well as Annex No 19 („Safety management system").

The Chicago Convention was created at a time when warfare were still underway. The year 1944 increasingly brought the end of World War II closer, at the same time, states were conducting intensive diplomatic efforts to regulate the international order based on the universal collective security system. That year, the action was underway on codification of international law in various fields, e.g. financial or aviation ${ }^{\mathrm{v}}$. Regarding the latter, the state of aviation since the adoption of the first universal international convention in this field in 1919 (Paris Convention) changed and more transparent rules were needed to take into account a different dimension of safety.

Air transport safety is a fundamental issue for countries, carriers, airports, passengers, institutions providing air navigation services, air traffic control units. A safe environment must be ensured by the state through relevant provisions in international aviation law. In the original version of the Chicago Convention, the provision on aviation safety was extremely limited.The Contracting Parties have assumed, in accordance with Article 3 (d), when issuing regulations for their state aircraft, that they will have due regard for the safety of navigation of civil aircraft. Thus, the state was obliged to implement national legal regulations taking into account the safety of air transport, both civil and state. This laconic expression assigned to individual countries the whole burden of introducing safety standards in air transport. No consequences were foreseen. The dynamically developing aviation industry has shown a number of errors in this area. Nobody supposed that the planes would also be used contrary to their purpose, i.e. as a means of killing or kidnapping people for ransom or other purposes of kidnappers.

In 1984, Article 3bis was introduced into the Chicago Convention, according to which all states must refrain from resorting to the use of weapons against civil aircraft in flight and that, in case of interception, the lives of persons on board and the safety of aircraft must not be endangered ${ }^{\mathrm{vi}}$. In accordance with art. 3 bis (b) is entitled to require the landing at some designated airport of a civil aircraft flying above its territory without authority or if there are reasonable grounds to conclude that it is being used for any purpose inconsistent with the aims of this Convention; it may also give such aircraft any other instructions to put an end to such violations. The State may order the aircraft crew (the aircraft commander) to comply with all instructions. For this reason, States may use States may use "any appropriate means". If this was the provision of this 
paragraph, it would mean the possibility of using a weapon, i.e. shooting down an aircraft. However, this provision contains an extension stating that these measures must comply with generally applicable principles of international law, including those set out in Article 2 of the Charter of the United Nations.Due to the fact that currently all states that have ratified the Chicago Convention are members of the United Nations, they are obliged to respect the rights and obligations arising from the Charter and other international agreements. The instruction contained in Article 3bis (a) contains a clear and unquestionable order to refrain from resorting to the use of weapons against civil aircraft in flight and that, in the event of interception, the lives of persons on board and the safety of the aircraft must not be endangered in any way.

The emergence of terrorist attacks against civil aviation safety in the mid-twentieth century forced countries to quickly change towards harmonizing the rules of conduct with persons violating the safety of air transport. The individual approach is pointless because aviation is mainly of international nature and international transport is the essence of the development of civil aviation. Therefore, it was necessary to develop common standards and implement them as soon as possible. As a result of this action, an international system preventing aviation from terrorism was created (the so-called Tokyo-Hague-Montreal system). It is based on the following conventions:

a) The Convention on Offences and Certain Other Acts Committed on Board Aircraft, signed in Tokyo on14 September 1963 (Tokyo Convention),

b) The Convention for the Suppression of Unlawful Seizure of Aircraft, signed in Hague on 16 December 1970 (Hague Convention),

c) The Convention for the Suppression of Unlawful Acts against the Safety of Civil Aviation, signed in Montreal on 23 September 1971 (Montreal Convention).

At the same time, new international aviation security regulations were introduced by adopting Annex 17 to the Chicago Convention. This happened relatively late, March $22^{\text {nd }}, 1974$, i.e. thirty years after the adoption of the convention. The damage, not only personal but also material, caused by terrorist acts was enormous at that time. Generally, this concerned the use of aircraft as a means of destroying a specific target on Earth.

The adopted system is an organizational, legal and functional framework regarding safety in international air traffic. It is worth emphasizing here that these multilateral regulations apply only in the international sphere, while domestic flights, which are subject to national regulations, are excluded. Regarding the safety of aircraft and protection against illegal capture, these issues are most fully regulated by the Hague Convention. It contains a clear statement of unlawful seizure of aircraft, placing this act in the category of "crime". In accordance with its Article 1, any person who on board an aircraft in flight: 


\section{International Journal of Social Science and Economic Research}

ISSN: 2455-8834

Volume:05, Issue:09 "September 2020"

a) unlawfully, by force or threat thereof, or by any other form of intimidation, seizes, or exercises control of, that aircraft, or attempts to perform any such act, or

b) is an accomplice of a person who performs or attempts to perform any such act commits an offence".

There are two very important elements to this definition. First, attempt to commit it was also classified as a crime. Secondly, it is extremely important to recognize an accomplice as a criminal. Such a person will be liable to the same extent and according to the same criteria as the principal offender. It should be noted that the prosecution of these perpetrators is possible only if the perpetrator did so on board the aircraft "in flight". Therefore, it was necessary to include a definition of the term in the convention. The aircraft was considered to be in flight from the moment the embarkation was completed and all the exterior doors were closed, until one of those doors was opened for disembarkation". However, if there was a forced landing, it is assumed that the flight lasts until the competent authorities take over responsibility for the aircraft and for persons and property on board.

One more important reservation has been made in the Hague Convention. Since this is an international multilateral agreement, it applies only if the place of take-off or final landing of the aircraft on which the offense was committed within the meaning of this Convention is located outside the territory of the State of registration of that aircraft.This applies to both international flights (so-called fifth, sixth or seventh air freedom) and domestic flights (so-called eighth freedom, i.e. cabotage). This expression seems to be justified, because if such an act took place on board an aircraft performing only domestic flight on the territory of the country of registration of that aircraft, then the provisions of the internal law of that country shall apply.An exception to this rule is a situation, only if the perpetrator or the alleged perpetrator of the crime finds themselves on the territory of a country other than the country of registration of that aircraft.

Regardless of where the perpetrator or the alleged perpetrator of the crime is, the signatory states of the Hague Convention must detain such a person. Action should be taken immediately to clarify all circumstances and establish the facts. Should the perpetrator of the crime prove to be a citizen of a country other than the one in which he was detained, extradition should be carried out against him. Pursuant to the provisions of the Convention, this may be the case when an extradition agreement exists between two countries. However, if the state does not want to hand over the perpetrator-citizen of another country, it is obliged to immediately commence criminal proceedings against him on the basis of its own internal regulations ${ }^{\text {vii }}$.

\section{Safety provisions in bilateral agreements}

Bilateral air services agreements are concluded based on the Chicago Convention (the so-called Chicago-bilateral system). For many decades they formed the basis for the operation of air 


\section{International Journal of Social Science and Economic Research}

ISSN: $2455-8834$

Volume:05, Issue:09 "September 2020"

transport between countries. They were very restrictive, they limited the freedom of market access and fair competition. Yet, global aviation liberalization processes initiated in 1978 in the USA and then in 1986 in Europe led to the modification of these agreements towards more open, enabling the development of air communication between countries. Today, both the first and the second agreements are in force, with the predominance of the latter. It can also be seen in European Union that bilateral agreements have been completely abolished between Member States and replaced by the principle of the European open sky. In accordance with art. 149 of the Treaty on the Functioning of the European Union (TFEU), there is freedom to operate between Member States, therefore this also applies to air transport and may not be subject to any restrictions in connection with the operation of aviation activities of one entity from one Member State in another Member State. Freedoms enshrined in basic normative acts of the European Union, i.e. freedom of establishment and the prohibition of discrimination on grounds of nationality are the highest values on which the functioning of the European Union is based.

It is worth to recall, that the first bilateral air transport agreements concluded between States from the 1920s did not contain safety clauses. It was not until the late 1980s and early 1990s that

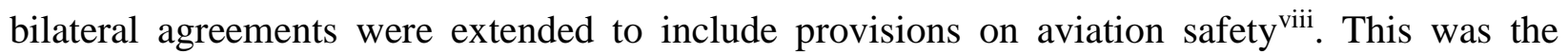
result of the adoption of relevant security conventions and a response to current conditions in the air transport sector.

We can distinguish two different types of clauses: safety clause and security clause. When analyzing this first type of clause, the provisions in bilateral agreements generally refer to consultation or "ramp inspection" procedures, or both in relation to an air carrier. States reserve the right to request consultations at any time on safety standards of a second State regarding an air carrier operating between countries, including crews, aircraft and their operation. In the case of EU (horizontal) agreements, they contain references to EU legal acts in the field of aviation safety that must be met by a third-country carrier wishing to perform operations in the EU. If, after such consultations, one country finds that the other does not sufficiently meet/control the fulfillment of the requirements by the registered carrier, then it will be notified of the need to take necessary measures to ensure these minimum standards, and a ban on flying in the European airspace will be applied until meeting all European standards.

Bilateral agreements may also include provisions regarding so-called ramp inspections of aircraft registered in third countries. Any aircraft operated by a carrier of one Party may be inspected during its stay on the other Party's territory. In accordance with the principle of reciprocity, such inspections may also be carried out in third countries in relation to EU carriers. If, during such an inspection on the ground, or a series thereof, serious reservations arise as to whether an aircraft or its operation meets the minimum standards established at that time under the Chicago 


\section{International Journal of Social Science and Economic Research}

ISSN: $2455-8834$

Volume:05, Issue:09 "September 2020"

Convention, so in such a situation, it is possible to prohibit the flight of a given aircraft over the EU area, or to extend the ban to all aircrafts of a given air carrier.

In the event that the carrier refuses access to conduct ramp inspections on the aircraft, then the State wishing to carry out such an inspection may immediately suspend or change the operating authorization issued to that carrier.Bilateral agreements also contain provision that in case the competent aviation authority takes action regarding non-compliance with the minimum standards by the carrier of the other Party, it will immediately inform the other aviation authorities, stating the reasons for such action.

As regards aviation security clause in bilateral agreements, they contain references to relevant conventions in this field. The Parties reaffirm their mutual obligations regarding aviation security against acts of unlawful interference. In this regard, they shall comply with the Chicago Convention of 1944, the Tokyo Convention of 1963, the Hague Convention of 1970 and the Montreal Convention of 1971. Sometimes a reference to the 1988 Montreal Protocol on aviation security at airports is also added. In contrast, European Union's bilateral horizontal agreements contain references to legal applicable to carriers and airports in this regard.Usually one annex to such an agreement enumerates the adopted EU legislation in this respect.

In addition, the agreements concluded by the Member States of the EU refer to compliance with the standards and recommended practices on aviation security established by ICAO and annexes to the Chicago Convention. In the event of a particular threat, the parties to the agreement will respond positively to requests for special protection measures. Parties mutually agree to comply with internal security regulations.

One provision is that the Parties shall provide each other with all necessary assistance in preventing acts of unlawful seizure of civil aircraft and other unlawful acts directed against the safety of such aircraft, their passengers and crews, airports and navigation devices, as well as other threats to civil aviation safety. This provision is identical in two different types of agreements. In the event of an act of unlawful seizure of a civil aircraft, or a threat thereof, or other unlawful acts directed against the safety of such a ship, its passengers and crew, airports or navigation equipment, the Parties shall provide each other with assistance by facilitating communication and other appropriate measures aimed at quick and the safe ending of such an event or threat of its occurrence.

\section{The nature of air accidents investigation}

State policy must guarantee every user of the airspace and all related to the aviation industry participants, that it will make every effort to ensure that from the legal point of view all standards of the provision of air services are safe. The state must create mechanisms for control of non- 


\section{International Journal of Social Science and Economic Research}

ISSN: $2455-8834$

Volume:05, Issue:09 "September 2020"

compliance with legal solutions. However, they must be uniform in relation to various entities (air carriers, passengers being citizens of different countries) due to the international nature of civil aviation. Therefore, ICAO has adopted appropriate provisions so that in the case of air accidents and incidents, each country follows uniform, harmonized rules.

It is very important that the international aviation law strictly regulates the issues of "air accident" and "air incident", and this can be found in Annex 13 to the Chicago Convention. Every country in the world is obliged to accept and implement procedures resulting from this annex.

The definition of ,an accident” is found in the chapter One of the Annex and means an occurrence associated with the operation of an aircraft which takes place between the time any person boards the aircraft with the intention of flight until such time as all such persons have disembarked, in which:

a) a person is fatally or seriously injured as a result of:

- being in the aircraft, or

- direct contact with any part of the aircraft, including parts which have become detached from the aircraft, or

- direct exposure to jet blast

except when the injuries are from natural causes, self-inflicted or inflicted by other persons, or when the injuries are to stowaways hiding outside the areas normally available to the passengers and crew; or

b) the aircraft sustains damage or structural failure which:

- adversely affects the structural strength, performance or flight characteristics of the aircraft, and

- would normally require major repair or replacement of the affected component, except for engine failure or damage, when the damage is limited to the engine, its cowlings or accessories; or for damage limited to propellers, wing tips, antennas, tires, brakes, fairings, small dents or puncture holes in the aircraft skin; or

c) the aircraft is missing or is completely inaccessible.

An incident is called an occurrence, other than an accident, associated with the operation of an aircraft which affects or could affect the safety of operation. There is also an intermediate category between the two above mentioned, namely 'serious incidents'. These are incidents involving circumstances indicating that an accident nearly occurred.

Incidents happen more often than accidents. The use of appropriate protection measures requires the cooperation of many institutions, which must coordinate their decisions and actions taken. Thanks to modern technologies, constant contact of the aircraft commander (pilots) with other 


\section{International Journal of Social Science and Economic Research}

ISSN: $2455-8834$

Volume:05, Issue:09 "September 2020"

relevant security authorities on the ground is possible. There are three reasons, incident prevention requires quick identification and analysis of the situation. First, you need to be able to identify suspicious behavior. In this regard, it is necessary that flight staff are properly trained. Secondly, the situation on the aircraft must be described. It is about indicating what is happening on board and following the instructions of the aircraft commander as the most important person. Thirdly, the risk of danger and what consequences it will have for others should be assessed. All incidents cannot be avoided. If personal or technical factors fail, an accident can occur.

The main and only purpose of investigating aviation accidents and incidents is to prevent similar situations in the future. The investigation is conducted by the country in which the accident took place. The State conducting the investigation must conduct it in accordance with the international standards set out in Annex No. 13 to the Chicago Convention. Regarding the participation of other countries in the accident investigation process, they may appoint an accredited representative with their advisers. The investigation must be completed by the final report. Earlier, the state conducting the investigation is required to submit an initial report, to which comments may be submitted by the state which will later receive the final report.The final report must be sent by the country conducting the investigation to the following: State instituting the investigation, State of Registry, State of the Operator, State of Design, State of Manufacture, State having interest because of fatalities, as well as State providing information, significant facilities or experts.

The terminology proposed in international regulations regarding incidents and accidents has been transposed into the national legal systems of each country. Some regional agreements have also adopted similar internal solutions, e.g. the European Union. It should be noted, therefore, that harmonization of provisions regarding the investigation of aviation accidents has been made, as this has a fundamental impact on the safety of the entire aviation environment. Thanks to this, there is no risk that the state will misinterpret a particular event and, as a consequence, draw wrong conclusions. This is also prevented by a standardized procedure associated with the investigation of the causes and circumstances of the event.

The investigation of aviation accidents serves to prevent similar situations in the future. Determining the causes and circumstances of such an accident and indicating appropriate solutions contributes to the development of better training methods and standards, as well as to the improvement of the technical condition of aircraft and air equipment. Also taking into account the fact that aviation does not have a purely local or national dimension, but operates internationally, the investigation of aviation accidents must be characterized by harmonized standards. Harmonization of regulations and consistent interpretation of procedures on a global scale allows for a quick implementation of recommended solutions and avoid the occurrence of a 


\section{International Journal of Social Science and Economic Research}

ISSN: $2455-8834$

Volume:05, Issue:09 "September 2020"

multitude of regulations that reduce the level of flight safety. International aviation is the field that requires cooperation and exchange of experience.

\section{The role of a State's airport safety and security policy}

An important role of the state in maintaining safe civil aviation is the highest level of safety and security at airports. States require airport owners to meet certain minimum security requirements, which are set out in both international standards and regional or national regulations. The policy of each country must be aimed at ensuring that all users, but also the entire society, feel safe and secure at each airport. It is actually airports that often gather from hundreds to tens of thousands of people a day. Every element of the airport's safety chain must be tight. It is the State that is responsible for the final supervision of the correct compliance of procedures by all airport's users. International recommendations and standards have been adopted regarding airport security requirements for which the state is responsible. The aviation authorities are safeguarding the entire society, because the air transport sector is extremely vulnerable to terrorist attacks and various dangerous acts referred to in the Montreal Convention of 1971 or the subsequent Montreal Protocol of 1988 regarding illegal acts committed at an airport.

In the 21 st century, airport safety and security became a priority in aviation policy. The main role of the State is to create such an aviation policy as well as its mechanisms and to develop appropriate measures in order to ensure safety for all entities. The airport is a public, open place, which means that anyone can stay in it, including terrorists. They can attack not only passengers waiting for the plane or disembarking, but also planes standing on the apron, or even the airport itself can be the object of an attack. Other ground devices (air traffic control, or adjacent emergency services buildings) may also be subject to attack. The attacks/bombings carried out at the airport can cause huge personal and financial losses. For example, on June $28^{\text {th }}$, 2016, at the Turkish Ataturk Airport in Istanbul, in front of the main hall and in the parking lot, a series of three explosions occurred. Media announced, 41 people were killed and 239 injured or seriously injured $^{\text {ix }}$. This attack was attributed to the Islamic State. This attack occurred despite the checkpoints before entering the airport's main hall. Airports are a great target for bombers, as such attacks cause panic, fear and anxiety in the whole society, and often around the world.

The State's aviation policy defines security measures and mechanisms to ensure the safety of all airport users, including passengers, crew, ground handling services providers, dealers, and the security of aircraft and all airport facilities.

The existence of airport safety and security services must be supported by technical equipment or an electronic monitoring system. The security control policy is carried out by the following means: 


\section{International Journal of Social Science and Economic Research}

ISSN: $2455-8834$

Volume:05, Issue:09 "September 2020"
a) manual control,
b) visual inspection
c) X-ray device
d) walk-through metal detectors (WTMD),
e) hand held metal detection (HHMD),
f) explosive detection dogs,
g) shoe explosive detection equipment (SED)
h) explosive vapour detection equipment (EVD).
i) explosive trace detection (ETD).

However, with regard to the procedure of checking of liquids, gels and aerosols, similar checking measures are applied as in the case of cabin baggage, except that instead of manual screening, a taste check or skin surface test is carried out. In addition, the other control means are also test strips for testing chemical reactions, and scanners for liquids in bottles.

An important element of aviation policy in the field of security at each airport is the security control of persons and baggage. While the security check of people is simple, because it concerns whether the person is not subject to a ban on flights or whether the person is not a disruptive passenger, the baggage check requires greater precision and knowledge of regulations and procedures in this respect. It is at the airport that the luggage is checked and special airport services are responsible for whether the passenger will be able to bring the item on board. Walking through the control procedure at the airport is nowadays the norm and is an acceptable form of protection due to flight safety. However, not all passengers know the procedures, especially if they are at the airport for the first time or rarely use it. Passengers who regularly or frequently use airports are familiar with the procedures and passing security checks is faster. Kirchenbaum distinguishes four types of human behavior at airport security check-ins:

a) full knowledge of the regulations - the passenger passes the checkpoint efficiently and without interference,

b) acceptance of instructions - the passenger accepts the instructions of the services regarding the removal of prohibited articles,

c) negotiating - if a prohibited item is detected, the passenger tries to negotiate with the security officer the possibility of bringing the item on board the plane, consequently acknowledging the security officer's right,

d) refusal - the passenger refuses or disagrees with the security guard's instructions ${ }^{\mathrm{x}}$.

After the terrorist attacks on New York and Washington in September 2001, the regulations on bringing various objects and substances on aircraft became extremely strict. After a few years, some regulations, which were very restrictive, were mitigated, but strict regulations still apply to 


\section{International Journal of Social Science and Economic Research}

ISSN: $2455-8834$

Volume:05, Issue:09 "September 2020"

items and substances brought on board the aircraft. We call them prohibited items. Every carrier has its own rules, however, there are international standards that have to be applied. The air carrier cannot introduce its own rules which are against State's policy and legal acts. The State gives the minimum standards every entity is obliged to implement. In Europe we have the definition of such prohibited items, which can be commonly accepted. In accordance with Article 3 (7) of the Regulation of the EU No 300/2008, means weapons, explosives or other dangerous devices, articles or substances that may be used to commit an act of unlawful interference that jeopardises the security of civil aviation. A security check, as discussed above, is needed to detect these items. Thanks to modern and technologically advanced systems, with the support of people and often dogs, you can detect transported goods or substances that should not be in the luggage carried by the aircraft.

The safety and security policy defines emergency procedures. Aviation policy must specify the basis for the operation of safety and security services and respond to all threats. By combining different personal and technical means, and their proper coordination, you can achieve the highest level of security. Therefore, there are specialized services at the airport in the field of security, such as: Border Guard, customs service, airport security service, or other operational services that are part of the entire airport security system. In addition, we are dealing with a wide range of technical measures, in the form of closed-circuit television cameras (CCTV) for surveillance purpose, security gates, and other technical security means. The security of the airport depends on the combination of these elements and their proper enforcement and application. The management of such system requires high qualifications from the personnel as well as organizational, operational and proper education and skills ${ }^{\mathrm{xi}}$.

The security and security policy at airports and in its vicinity is strictly subject to international regulations. All airport facilities and equipment are subject to regulations that must be met in order to obtain permission to use such an airport. The basic regulations in this respect are the provisions of Annex 14 to the Chicago Convention, as well as the provisions of other annexes and documents issued by ICAO bodies, mainly the Council. Safety plays a key role in the design, construction and operation of every airport. Any deviation from the standards endangers aircrafts and passengers. The security policy also applies to airport's objects, airport personnel and services, animals, as well as the airport environment. The level of protection for rescue and firefighting must correspond to a particular category of airport and aircraft which are used.

The presence of animals, including birds at and around airports, poses a serious threat to the safety of aircraft operations, as referred to in point 9.4 of Chapter 9 of Annex 14 to the Chicago Convention. Therefore, in order to reduce the risk to aircraft operations, each airport must implement measures that minimize the likelihood of aircraft colliding with animals.. Therefore, the existence or establishment of garbage dumps attracting birds is absolutely banned near the 


\section{International Journal of Social Science and Economic Research}

ISSN: $2455-8834$

Volume:05, Issue:09 "September 2020"

airport. Airports must also have a fence that prevents potential animals from entering the ground movement area.

Safety when servicing aircraft is also extremely important. Each airport must provide rescue and fire-fighting services equipped with rescue and fire-fighting equipment. In the vicinity of ground-handling activities, including in particular refueling, firefighting equipment and personnel trained for its operation must be available and ready for use. It must also be possible to immediately call and arrive of the rescue and fire-fighting services in the event of a fire or spilled fuel. Procedures for evacuating passengers from such locations must be included in the overall airport safety and security plan. Rescue and firefighting personnel must have appropriate periodic training, including practical participation in fire-fighting exercises. Detailed guidelines for the design of the training program for rescue and fire-fighting personnel are contained in the "Human Factors Training Manual” (Doc 9683, ICAO Document, 1998).

Vehicle traffic within the airport area is also strictly regulated, in accordance with the standards set out in point 9.7 of Chapter 9 of Annex 14 to the Chicago Convention. Only authorized vehicles can enter the airport. The airport control tower (TWR) gives permission to use vehicles in the maneuvering area, while the airport managing body gives permission to use vehicles on the apron. These vehicles may be used by service employees or authorized persons. Drivers of such vehicles must follow all instructions resulting from road markings, vertical signs and traffic lights. They are also obliged to maintain constant radio communication with the airport control tower before entering the maneuvering area and with the authorized airport management body before entering the apron. As for the rescue vehicles involved in the action, they have priority over all other ground participants.

Each airport management body must have, in order to eliminate the threat, an action plan appropriate to the threats occurring at the airport or in its vicinity, in accordance with the guidelines contained in the document "Airport Services Manual" issued by ICAO(Doc 9137, ICAO Document, 1983 with amendments). These potential threats include:

a) threat of using explosives on board aircraft or airfields,

b) unlawful seizure of aircraft,

c) incidents with hazardous materials,

d) fires of buildings,

e) natural disasters,

f) the risk of passengers/cargo spreading serious infectious diseases in international air transport.

All airport services must be constantly prepared to take action to ensure or restore security. They must be ready to resolve the emergency in all conditions. Each airport must have an action plan 


\section{International Journal of Social Science and Economic Research}

ISSN: $2455-8834$

Volume:05, Issue:09 "September 2020"

for specific emergency services for each flight operation and any other type of activity at the airport. The action plan adopted by the airport management body must ensure coordination of activities and participation of all bodies that, in the opinion of the competent authorities, could help in managing the emergency. We can divide such bodies into two categories. First category of bodies are those acting within the airport, so in particular: air traffic control unit, rescue and firefighting services, airport administration, medical and sanitary services, users of aircraft, security and police services. The other category of bodies outside the airport area are the following: fire brigades, police, medical and sanitary services, hospitals, military units, seaport and coastal security services. The essence of each plan should be the coordination and cooperation of various types of services at a specific threat. Due to the possibility of an emergency situation, there must also be a permanent operational unit at each airport, which is responsible for comprehensive coordination and general management of emergency operations. The plan's effectiveness must be checked based on periodical rescue exercises.

The operation of rescue and firefighting services at the airport is extremely important, because the threat of fire and its effects can be enormous. In the event of a fire, the main purpose of these services is to save lives. Each airport must have a fire protection level appropriate to the category of airport specified in Annex 14 to the Chicago Convention. Each employee of the air rescue and firefighting services must be properly trained and qualified to work at the airport. The airport managing body has the responsibility to implement training and control programs to ensure a consistent level of qualification for these employees. In addition, all employees of rescue and fire-fighting services who are potentially required to participate in aviation rescue operations must undergo periodic medical examinations confirming their health condition enabling them to perform the assigned tasks, taking into account the type of activity. The health condition of these services is very important, both in terms of mental and physical health, because the occurrence of any illness or disability would stop employees from performing the activities necessary to conduct a rescue operation; performing their assigned tasks or proper perception of different threats.

Each airport must be prepared for a potential terrorist attack. The airport is a "perfect" place for terrorists, for the following reasons:

a) quite a large group of people in a relatively small place,

b) public show of such an attack,

c) causing social panic and fear in society.

In this regard, States must prepare appropriate airport security programs against acts of unlawful interference, as required by Annex 17 'Aviation Security' to the Chicago Convention. Each airport serving international civil aviation must develop, implement and update a written airport 


\section{International Journal of Social Science and Economic Research}

ISSN: $2455-8834$

Volume:05, Issue:09 "September 2020"

security program in accordance with the requirements of the national aviation security program, pursuant to Chapter 3, point 3.2 of Annex 17 to the Chicago Convention.

Each airport must have its own security system, whose detailed guidelines must be confidential due to the nature of the issue. Therefore, the opinions of all security services should be taken into account at the stage of planning and designing the airport. All measures contained in the airport planning manual (Doc 9184) must be implemented at every airport in the world. Regional rules must comply with these ones. The recommendation in ICAO Doc 9184 is generally the principle that each part of the airport should be separated from each other; the airport managing bodies and countries must show and give great importance to airport security issues.

Protecting the airport against acts of unlawful interference is an extremely important aviation policy today, as the threat posed by terrorists towards airports is very real. It should be noted, that not only national criminal regulations hold persons planning or attacking the airport or related infrastructure, but also European and international. Practical issues for airports are specified by each airport in its airport security plan. Such a document must be prepared by each airport management body and then approved by the appropriate aviation authority in a State, usually it is the Civil Aviation Authority in each country. The airport managing body, when developing such a document, designates security restricted areas and their critical parts, as well as the passing-by to these areas. The airport management body assisted by the airport security service is responsible for the safety of the restricted area, including security checks of persons and vehicles entering it $^{x i i}$.

\section{The safety of passengers in a global aviation policy nowadays}

Ensuring the safety of the society is one of the basic duties of the state. The relevant institutions deal with certain categories of safety and security. This institutional approach to the role of State security allows us to emphasize, that it is not only the air carrier or airport that is responsible for air safety of its passengers, but the State in particular through its institutions. The passenger feels safe in air traffic not only because it is guaranteed by a contract with the carrier, a high sense of security or quality of services, but because of the State's policy. By pursuing its aviation safety policy, the State guarantees to all passengers that the use of air traffic is completely safe. Therefore, the State fulfills not only the regulatory role performed by specific entities, but also the control/supervisory role, which is to monitor of all safety procedures.

The starting point for ensuring air safety for passengers is the general principle of aviation safety as set out in Article 3 (3) and Article 44 of the Chicago Convention. The State oversees safety compliance by all entities associated with aviation activities. 


\section{International Journal of Social Science and Economic Research}

ISSN: $2455-8834$

Volume:05, Issue:09 "September 2020"

All categories of passengers (departing, transfer, transit) are, in principle, subjected to security controls at the airport in order to prevent them from bringing prohibited articles to the airport and on board aircraft. For example, in Europe, transfer and transit passengers may be exempted from screening procedures if this applies to flights within the European Union (more broadly within the European Economic Area and Switzerland) arrive from one of the Member States, or if they arrive from a third country where the security procedures are in accordance with European procedures. In addition, transit passengers may also be exempted from screening when they remain on board the aircraft or have no contact with departing passengers, except for those departing from the same aircraft. The same applies to the luggage of the above passengers.

Passengers benefit from protection in many areas of aviation activities. Their safety is based on such principles as: information about the carrier actually performing the flight, baggage-related procedures, security in the event of cancellation, delay or denied boarding, and many more. There are no uniform international standards for passenger protection, but in the case of European aviation policy a number of passenger-friendly solutions have been established to ensure the safety of travel for every user.

The development of international aviation law under the Chicago system has not included the issue of protecting air passengers' rights. The 1999 Montreal Convention sets out the principles of carrier liability for damage arising in the event of the death or injury of a passenger, damage to luggage or cargo, and limits of compensation ${ }^{\text {xiii }}$. The passenger has a guarantee given by the State that movement in the airspace is safe. If the airspace is opened for air operations, so the State gives everyone the guarantee, that flying is safe and without any threats. If the government thinks a particular area is unsafe due to war or other meteorological reasons, it may close the airspace. We had in April 2010 in Europe such situation, when due to the eruption of EyjafjallajökullVolcano in Iceland, nearly all States in Europe closed their airspace wholly or partially for a week. Economic losses for aviation industry, airports, air carriers, passengers were enormous. There were also economic turbulences for the whole economy of a country. However, the safety of people was more important that economic condition of a State. Nonetheless, the opposite example is when in July 2014 the Malaysian Airlines aircraft was shot down by separatists in Ukraine over the territory, which was in an armed conflict with Russian Federation. The government didn't decide to close the airspace in this area where war action was undergoing. All the passengers and crew died because of that.

In Europe, we can stress, that there is a fully regulated aviation market, and EU countries and bodies have instruments to implement policies to protect air passengers' rights and ensure their safety in these aspects. Europe gives an unprecedented example of air passengers' protection. No other country or region has implemented such rules and standards to protect air passengers' rights in different situations. Passengers in Europe, but also European citizens when travelling 


\section{International Journal of Social Science and Economic Research}

ISSN: $2455-8834$

Volume:05, Issue:09 "September 2020"

around the world by European carrier, have the option of using a new civil aviation safety instrument, the so-called 'black list' of air carriers. This is an EU list of all air carriers in the world outside Europe that do not meet international and European safety standards and / or specific aircraft of individual carriers, which raise great reservations as to their technical condition, in accordance with EU Regulation 2111/2005 ${ }^{\text {xiv }}$. Everyone can check whether the air carrier is placed on such a list. When an aircraft or air carrier is placed on such a list, it indicates that the minimum security requirements by this air carrier according to European standards are not met. This is an important information for all passengers in the world, because it contains air carriers from different countries, and this will make it easier for passengers in these countries to identify potentially dangerous machines and air carriers. "Blacklist "is a guide for passengers' safety. Thanks to it, a person who has not yet started traveling by plane will be informed about the safety of the air carrier. The "black list" is also a warning for those who choose to travel by air in third countries, to take into account the failure to meet the high safety standards of a particular air carrier and its machines. And everyone can freely use air transport carried out within the EU, because air carriers that do not meet flight safety standards are deprived of the possibility of entering the EU airspace ${ }^{\mathrm{xv}}$.

\section{Summary}

Safety of air transport is guaranteed both by non-state entities such as air carriers or airports, and above all in the institutional and organizational dimension by state authorities that constantly monitor compliance with specific procedures, standards and recommendations. The dynamic technological development of passenger safety systems is implemented with a sense of responsibility for the safety of all air traffic, and therefore legal regulations must keep up with these changes. Since the beginning of the introduction of international standards, air traffic safety has been a priority for States. The practical application of standards is constantly evolving and adapting to the challenges of the contemporary world.

\footnotetext{
i Kraśnicka I., A Short Note on the Origins of the International Civil Aviation Organization on its 65th Anniversary, Miscellanea Historico-Iuridica, TOM XI, 2012, p.308.

ii Świerszcz, K.,(2016), Bezpieczeństwo państwa w czasach wspótczesnych w ujęciu podmiotowoaksjologicznych wyzwań, Przegląd Nauk o Obronności 1/2016,p.69.

iii Ibidem, p.71.

iv Zając, G., (2009), Wspólna polityka lotnicza Unii Europejskiej, Przemysl, p.130.

'The Bretton Woods system was created, which consists of two independent organizations: the World Bank (amended by the International Bank for Reconstruction and Development - IBRD) and the International Monetary Fund- IMF.

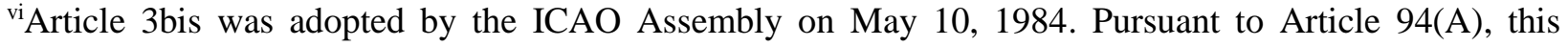
amendment entered into force on October 1, 1998.
} 
International Journal of Social Science and Economic Research

ISSN: 2455-8834

Volume:05, Issue:09 "September 2020"

viiiSeemore: Zając, G., (2011),Prawnomiędzynarodowe regulacje dotyczace zwalczania terroryzmu $w$ lotnictwie cywilnym, w: „Stosunki Międzynarodowe”, t.43 nr (1-2) 2011, Ed.Warsaw University, Warsaw, pp.105-120.

viii Zając, G., (2006), Dwustronne umowy o komunikacji lotniczej zawierane przez Polske, in: „Przegląd Sił Powietrznych", No 4/06, Ed. Dowództwo Sił Powietrznych RP, Poznan, pp.84-94.

${ }^{i x}$ https://www.bbc.com/news/world-europe-36658187, access on 23.01.2020.

${ }^{x}$ A. (Avi) Kirschenbaum, The cost of airport security: The passenger dilemma, "Journal of Air Transport Management" 30 (2013), p.41.

xi Zając, G.,(2016), Podstawy prawne i funkcjonowanie przewoźników lotniczych i lotnisk w Europie, Warsaw, p.449.

xii Zieliński, M., (2010), Bezpieczeństwo w porcie lotniczym, Zeszyty Naukowe Akademii Marynarki Wojennej, Rok LI Nr 4 (183),p.161.

${ }^{x i i i}$ Conventionfor the unification of certain rules forinternational carriage by air(Montreal Convention), done in Montreal, 28.05.1999, OJ L194, 18.7.2001.

${ }^{x i v}$ Regulation (EC) No 2111/2005 of the European Parliament and of the Council of 14 December 2005 on the establishment of a Community list of air carriers subject to an operating ban within the Community and on informing air transport passengers of the identity of the operating air carrier, and repealing Article 9 of Directive 2004/36/EC, OJ L 344,27.12.2005, pp. 15-22.

${ }^{x v}$ Zając, G., (2016), op.cit., p. 347. 